\title{
Notes on distribution of some portunid crabs in the Mediterranean Sea (Decapoda: Brachyura: Portunidae)
}

Milan Koch \& Zdeněk Ďuriš

\begin{abstract}
Notes on distribution of some portunid crabs in the Mediterranean Sea (Decapoda: Brachyura: Portunidae) - Acta Mus. Siles. Sci. Natur. 65: 117-128, 2016.

Abstract: Collections of benthic organisms were obtained during previous Soviet research cruises in the Mediterranean Sea, 1974-1980. Material was collected by bottom grabs or trawls from the depths of 20-500m. Collecting stations were allocated in the Aegean, Adriatic, Tyrrhenian, Balearic, Alboran, and Ionian Seas, and between Sicily and Tunisia. Among decapod crustaceans collected, 8 species of portunid crabs were present, i.e., Liocarcinus. corrugatus (Pennant, 1777), L. depurator (Linnaeus, 1758), L. maculatus (Risso, 1827), L. navigator (Herbst, 1794), L. vernalis (Pennant, 1816), L. zariquieyi Gordon, 1968, Macropipus tuberculatus (Roux, 1830), and Bathynectes longipes (Risso, 1816). For two species, L. maculatus and L. zariquieyi, new distributional records are presented here. An extension of the known depth range is reported here for L. maculatus and L. vernalis.
\end{abstract}

Keywords: bathymetry, Bathynectes, distribution, ecology, Liocarcinus, Macropipus

\section{Introduction}

Crabs of the family Portunidae Rafinesque, 1815 include recently over 300 species (De Grave et al. 2009) spread widely in seas and oceans of the World. As strictly predatory species, occurring predominantly on sandy bottoms, a lot of their species exhibit an ecological importance (Abelló 1989). Many portunids, due to their size and density, represent also object of a considerable commercial interest (Holthuis 1987).

The Mediterranean portunid fauna actually covers over 20 species from of about 12 genera and 4 subfamilies (Holthuis 1987; $\mathrm{Ng}$ et al. 2008). The number of species is still increasing due to human activities and also native migrations. Main man-made pathway for nowadays migration is the Suez Canal connecting the Mediterranean Sea and the Red Sea, established due Ferdinand de Lesseps and opened in 1869. This connection allowed to species from tropical regions to get to the Mediterranean by own way or due ships, e. g. in ballast water (Streftartis et al. 2005). On the basis of the establisher name is this migration called Lessepsian.

The native way for migration is the Gibraltar Strait connecting the Mediterranean with the Eastern Atlantic. In comparison with Suez, Gibraltar has actually lower importance for new species introduction (Streftaris et al. 2005).

This study focuses on the morphology, distribution and ecology of eight species of portunid Mediterranean crabs from the subfamily Polybiinae Ortmann, 1893, whose specimens were recognized from the collected material, namely from the genera Liocarcinus Stimpson, 1861, Macropipus Prestandrea, 1833, and Bathynectes Stimpson, 1861. The genus Liocarcinus is represented by eight, Bathynectes by two, and Macropipus only by a single species in the Mediterranean Sea (Bouvier 1940; Monod 1956; Zariquiey Álvarez 1968; Christiansen 1969; Holhuis 1987; Udekem d'Acoz 1999). In the presented material, six species were identified from the genus Liocarcinus while the others are represented by one species each. Obtained data contribute to recent knowledge on the distribution of the portunid crabs in the Mediterranean. 


\section{Material and methods}

Collections of benthic organisms were obtained during cruises of previously Soviet research vessel, Akademik A. Kovalevskii (Institute of Biology of the Southern Seas, National Ukrainian Academy of Science, Sevastopol) in the Mediterranean Sea, 1974-1980.

In a total, 125 collecting stations were allocatedin the Aegean (2 stations), Adriatic (8), Tyrrhenian (2), Balearic (52), Alboran (5), and Ionian (1) Seas, and between Sicily and Tunisia (55). Material was collected by bottom grab 'Ocean' and by Sigsbee and beam trawls from the bottom in depths of 20-500 m.

Portunid crabs were collected from 35 stations situated in the following regions: Alboran Sea (2 samples), Balearic Sea (11), Adriatic Sea (2), Aegean Sea (1) and between Sicily and Tunisia (19).

Crab specimens were preserved in $4 \%$ formaldehyde, later transferred to $70 \%$ ethylic alcohol. Most of the material reported will be deposited in the Zoological Museum of the Moscow State University, part in authors' collection (University of Ostrava).

The following abbreviations are used in the text: CL, the carapace length measured in the median line; CW, the carapace width - the greatest width of the carapace, including lateral teeth.

\section{SYSTEMATIC PART}

\section{Family Portunidae Rafinesque, 1815 Subfamily Polybiinae Ortmann, 1893}

\section{Genus Liocarcinus Stimpson, 1861}

\section{Liocarcinus corrugatus (Pennant, 1777) Figs 1 A-C, 9}

Portunus corrugatus. Palmer, 1927: 881, fig. 2; Bouvier, 1940: 240, fig 155, pl. IX, fig 5.

Macropipus corrugatus. Zariquiey Álvarez, 1968: 372, figs. 13 e, 118 c-e, 120 c, 122 d, 123 e, 124 c.

Liocarcinus corrugatus. Holthuis, 1987: 355.

Polybius (Necora) corrugatus. Udekem d'Acoz, 1999: 219.

Material examined. R/V „Akademik A. Kovalevskii“‘, 74th cruise: Stn.1192/129, 2 Jun. 1974, off eastern Spain, $40^{\circ} 3^{\prime} 60.00 " \mathrm{~N}-0^{\circ} 56^{\prime} 1.00^{\prime \prime} \mathrm{V}$, bottom grab 'Ocean', sand with broken shells, $105 \mathrm{~m}-1 \mathrm{spm}$, damaged. Stn.

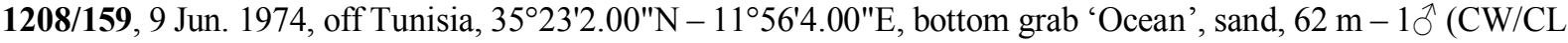
$8.1 \mathrm{~mm} / 7.0 \mathrm{~mm}), 2$ 우 (CW/CL 10.1, $9.6 \mathrm{~mm} / 8.9,8.2 \mathrm{~mm}$, resp.). 83th cruise: Stn. 1261/54, 24 Apr. 1978, off western Sicily, $37^{\circ} 26^{\prime} 8.00^{\prime \prime} \mathrm{N}-12^{\circ} 11^{\prime} 6.00^{\prime \prime E}$, Sigsbee trawl, rough sand with shells, $57 \mathrm{~m}-1$ juv. (CW/CL5.5 $\mathrm{mm} / 5.0 \mathrm{~mm})$. Stn.1268, 27 Apr. 1978, off Tunisia, 35॰10'8.00"N - 12³4'0.00"E, Sigsbee trawl, sand, 47-50 m $1{ }^{\Uparrow}$ (CW 12.7 mm, CL 10.5 mm), 3우 (CW/CL 9.0, 11.6, $13.5 \mathrm{~mm} / 7.5,9.9,11.4 \mathrm{~mm}$, resp.). Stn.1269/70, 28

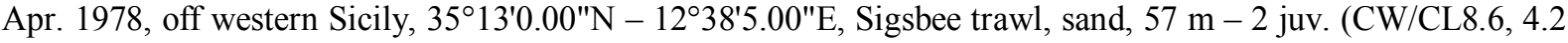
$\mathrm{mm} / 7.6,3.9 \mathrm{~mm}$, resp.). 87th cruise: Stn. 1303, 13 Sep. 1979, off Tunisia, 377'60.00"N - 12॰0 0'7.00"E, Sigsbee trawl, sand, $78 \mathrm{~m}-1$ 우 $(\mathrm{CW} / \mathrm{CL} 17.5 \mathrm{~mm} / 15.3 \mathrm{~mm}), 1{ }^{\top}(\mathrm{CW} / \mathrm{CL} 14.4 \mathrm{~mm} / 12.0 \mathrm{~mm})$. 89thcruise: Stn. 1390, 2 Sep. 1980, off Tunisia, $35^{\circ} 18^{\prime} 3.00^{\prime \prime} \mathrm{N}-12^{\circ} 4^{\prime} 4.00^{\prime \prime E}$, Sigsbee trawl, sand, $55 \mathrm{~m}-1{ }^{\lambda}$ (CW/CL 17.5/15.2 mm).

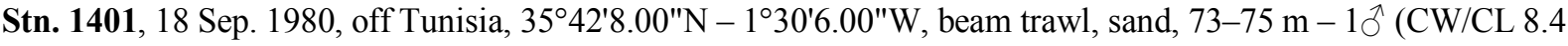
$\mathrm{mm} / 7.4 \mathrm{~mm})$.

Remarks. Fifteen specimens were examined - 5 males, 6 females, 3 juveniles and one strongly damaged specimen. A variability of the carapace size was found in the males with CW/CL 8.117.5/7.0-15.2 mm, and in females with CW/CL 9.0-17.5 mm/7.5-15.3 mm. The CW/CL ratio in all specimens was 1.07-1.21 (mostly over 1.1). The latter does not correspond with data previously reported by Palmer (1927) who mentioned a higher ratio, 1.27-1.29. This may be caused by small size of the specimens examined. Other characters fully agree with published descriptions (Palmer 1927; Bouvier 1940; Zariquiey Álvarez 1968; Holthuis 1987). Among the most important characters are: (1) front with three low lobes; (5) all of anterolateral teeth acute, subequal; (3) carapace with a lot of transversal ridges; (4) the cheliped carpus with a distinct tubercle on the outer surface and without a posterolateral angle; (5) 5th pereiopods with clearly visible keel on the dactylus and with a relatively broad propodus.

Habitat. The present specimens were collected from sand or rough sand with broken shells substrata, from depths of 47-110 m. Liocarcinus corrugatus was previously reported from sand, 

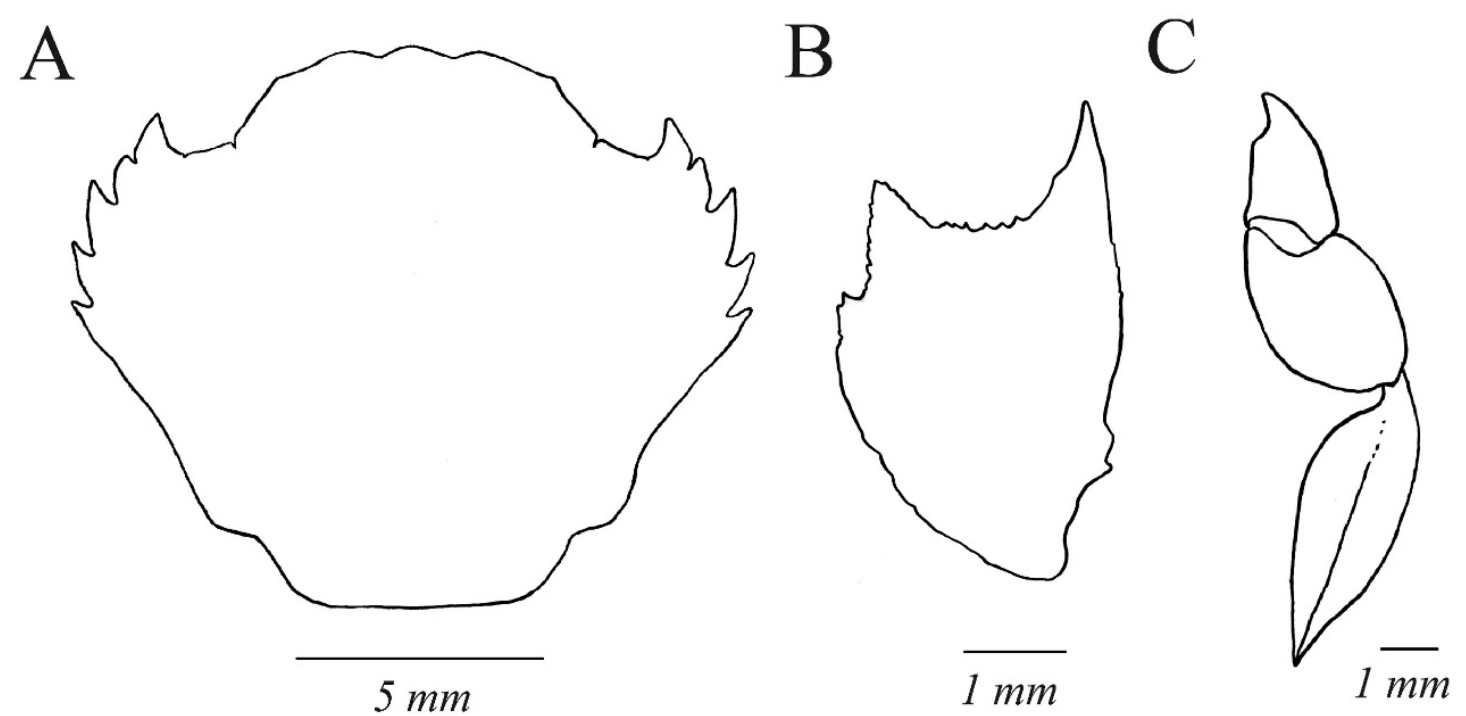

Fig 1: Liocarcinus corrugatus (Pennant, 1777). A, carapace; B, carpus of left cheliped; C, fifth ambulatory leg.
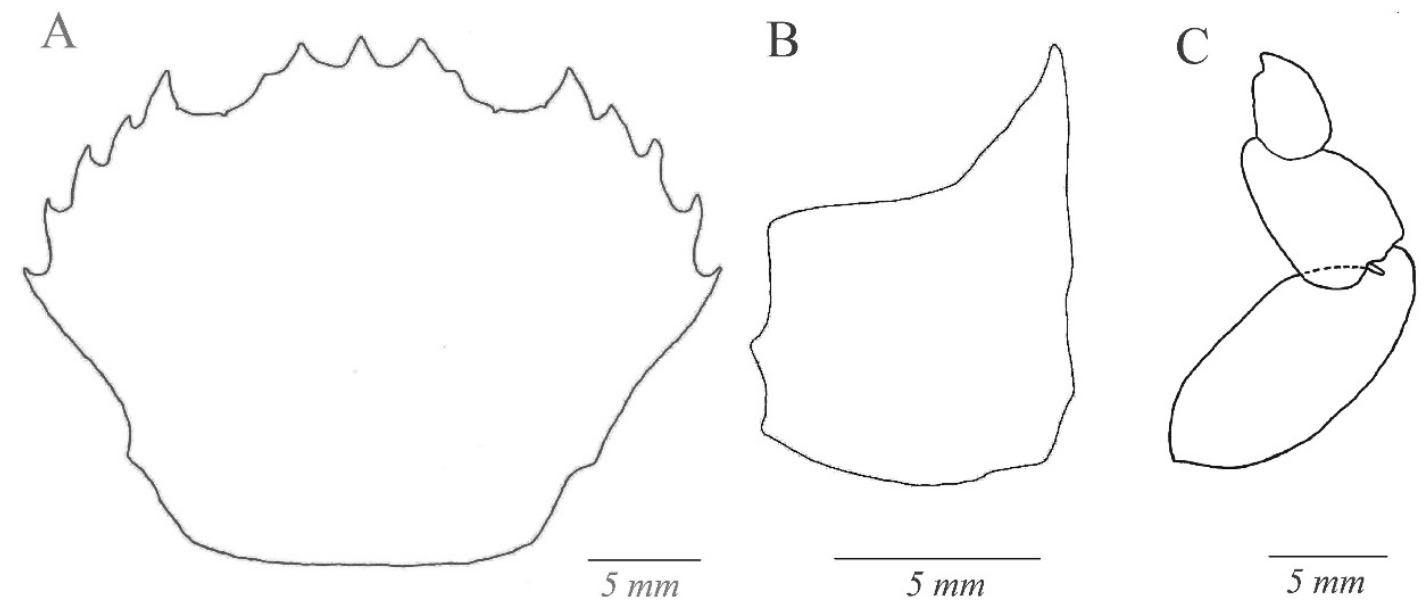

Fig 2: Liocarcinus depurator (Linnaeus, 1758). A, carapace; B, carpus of left cheliped; C, fifth ambulatory leg.

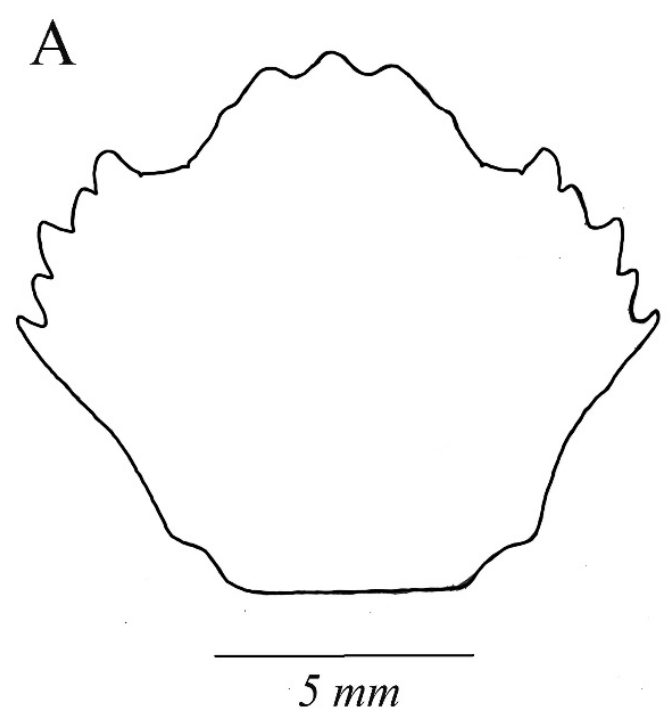

B
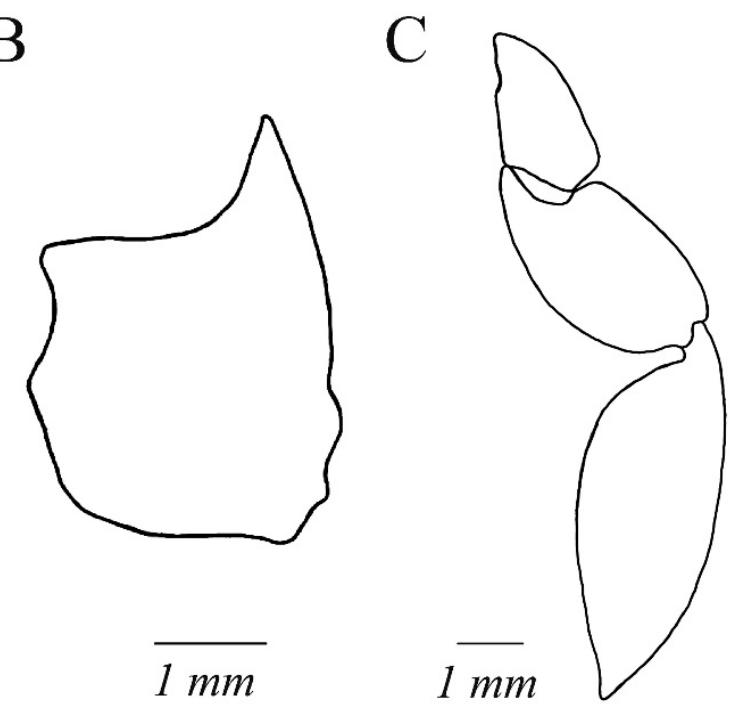

Fig 3: Liocarcinus maculatus (Risso, 1827). A, carapace; B, carpus of left cheliped; C, fifth ambulatory leg. 
mud or gravel bottom, in depths around 60 m (Zariquiey Álvarez 1968; Manning \& Holthuis 1981; Udekem d'Acoz 1999), Stephenson (1972) reported a female of that species from the depth of $180 \mathrm{~m}$.

Distribution. The distribution of this species is extensive. It has been reported from the Eastern Pacific (Japan, Australia and New Zealand) and from the Eastern Atlantic (from Angola to the Great Britain) and the Mediterranean (Stephenson 1972; Holthuis 1987). In the Mediterranean, the species was reported occupying mainly the western part, but there are reports also from Croatia, Cyprus and Egypt (Holthuis 1987). The present records from the eastern Spain, western Sicily, Alboran Sea and Tunisia match well with the known range of the species (Holthuis 1987).

\section{Liocarcinus depurator (Linnaeus, 1758) Figs 2 A-C, 9}

Portunus depurator. Palmer, 1927: 893-894, fig. 8; Bouvier, 1940: 242, pl. IX, fig 8.

Macropipus depurator. Zariquiey Álvarez, 1968: 376-377, figs. 1 g, 13 f, 14 d, 119 d, 121 d, 123 d, 124 e; Christiansen, 1969: 64-66, fig. 25; map 19.

Liocarcinus depurator. $\mathrm{Ng}$ et al., 2008: 149.

Polybius (Polybius) depurator. Udekem d'Acoz, 1999: 221.

Material examined. R/V ,Akademik A. Kovalevskii““, 74th cruise: Stn. 1111/30, 2 May 1974, the Adriatic Sea, $43^{\circ} 21^{\prime} 07.00^{\prime \prime} \mathrm{N}-14^{\circ} 46^{\prime} 09.00^{\prime \prime E}$, bottom grab 'Ocean', clayish sand with broken shells, $110 \mathrm{~m}-2$ 우 (CW/CL 23.5, $26.8 \mathrm{~mm} / 17.8,20.3 \mathrm{~mm}$, resp.), $1 \delta^{\top}$ (CW/CL $26.2 \mathrm{~mm} / 20.4 \mathrm{~mm}$ ). Stn. 1135/54, 5 May. 1974, the Adriatic

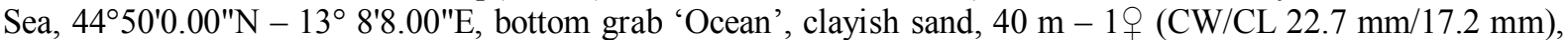
$1 \widehat{\jmath}(\mathrm{CW} / \mathrm{CL} 25.8 \mathrm{~mm} / 19.8 \mathrm{~mm})$. Stn. 1182/129, 1 Jun. 1974, off eastern Spain, 40¹7'8.00"N - 047'8.00"E,

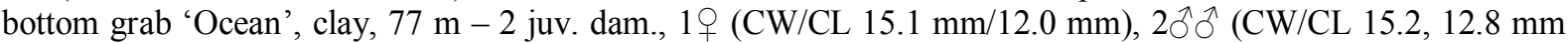
/12.4, 10.2 mm, resp.). 83 th cruise: Stn. 1247, 9 Apr. 1978, off eastern Spain, 40²6'2.00"N - 1 ${ }^{\circ}{ }^{\prime} 2.00^{\prime \prime E}$, bottom grab 'Ocean', clayish sand $90 \mathrm{~m}-2$ - $ᄋ$ (CW/CL 12.6, $33.2 \mathrm{~mm} / 10.1,24.7 \mathrm{~mm}$, resp). Stn. 1252, 15 Apr. 1978, off eastern Spain, 40¹1'5.00"E - 0 55'4.00"E, bottom grab 'Ocean', clayish sand, $90 \mathrm{~m}-1$ juv. (CW/CL 8.0 mm/6.3 mm). Stn. 1254, 15 Apr. 1978, off eastern Spain, 40³'2.00"N - 055'3.00"E, bottom grab 'Ocean', clayish sand, $70 \mathrm{~m}-1$ 우 (CW/CL $21.4 \mathrm{~mm} / 16.5 \mathrm{~mm})$. Stn. 1256, 16 Apr. 1978, off eastern Spain, 40¹1'6.00"N - 048'9.00"E, bottom grab 'Ocean', clayish sand, $75 \mathrm{~m}-1 \delta^{\Uparrow}$ (CW/CL 53.6/39.5 mm). Stn. 1257, 16 Apr. 1978, off eastern Spain, 40 $2^{\prime} 60.00^{\prime \prime} \mathrm{N}-0^{\circ} 52^{\prime} 6.00^{\prime \prime} \mathrm{V}$, bottom grab 'Ocean', sand with shells, $94 \mathrm{~m}-1$ ( $(\mathrm{CW} / \mathrm{CL}$ $35.4 / 26.8 \mathrm{~mm}$ ). 89th cruise: Stn. 1355, 16 Apr. 1980, off eastern Spain, 40¹2'5.00"N - $0^{\circ} 47^{\prime} 0.00$ "E, bottom grab 'Ocean', clayish sand, $76 \mathrm{~m}-1$ + juv. (CW/CL $13.0 \mathrm{~mm} / 10.0 \mathrm{~mm}$ ).

Remarks. The total number of the examined specimens was seventeen: 9 females, 5 males and 3 juveniles. The range of the carapace size in the males was CW/CL $12.8-53.6 \mathrm{~mm} / 10.2-39.5$ $\mathrm{mm}$, and in the females CW/CL 13.0-35.4 mm/10.0-26.8 mm, while the CW/CL ratio was 1.22-1.35. Morphological characters correspond with previous descriptions (Bouvier 1940; Zariquiey Álvarez 1968; Christiansen 1969), mainly: (1) the front with three distinct sharp teeth; (2) all anterolateral teeth of subequal size; (3) the cheliped carpus with a clearly visible posterior outer angle and with a distinct tubercle on the outer surface; (4) the dactylus of 5th pereiopods broad and ovoid.

Habitat. Inhabited depths, according to Christiansen (1969), reach down to $450 \mathrm{~m}$, but the common depth is of about $100 \mathrm{~m}$. This fact fully corresponds with the depth range of the present samples containing the actual species $(40-110 \mathrm{~m})$. There is probably no preferred substrate; sand, rock, gravel, mud, as well as their combinations, are mentioned in Christiansen (1969).

Distribution. Liocarcinus depurator is very common species. Its areal covers coasts of NW Africa and reaches northwards to the middle of Norway. It was reported from almost the whole Mediterranean, and occasionally also from the Black Sea (Holthuis \& Gotlieb 1958; Zariquiey Álvarez 1968; Christiansen 1969; Ateş 1999). In the Mediterranean, distributional data are lacking from the south-eastern basin, e.g., from Libya and Egypt (Holthuis 1987). Our samples are from the eastern coast of Spain and from the Adriatic Sea, from which regions the species was previously reported (e.g., Zariquiey Álvarez 1968, Števčić 1969). 
Liocarcinus maculatus (Risso, 1827) Figs 3 A-C, 9

Portunus pusillus. Monod, 1956: 176, figs. 203, 204.

Macropipus pusillus. Zariquiey Álvarez, 1968: 372.

Liocarcinus maculatus. Froglia \& Manning, 1982: 260-262, fig. 1 a-d.

Polybius maculatus. Udekem d'Acoz, 1999: 101.

Material examined. R/V ,Akademik A. Kovalevskii“6, 74th cruise: Stn. 1199/138, 3 Jun. 1974, off eastern Spain, $40^{\circ} 8^{\prime} 60.00^{\prime \prime} \mathrm{N}-0^{\circ} 42^{\prime} 0.00^{\prime \prime E}$, bottom grab 'Ocean', sand with broken shells, $78 \mathrm{~m}-1 \delta^{\lambda} \mathrm{dam}$. (CW/CL 5.5 mm/5.0

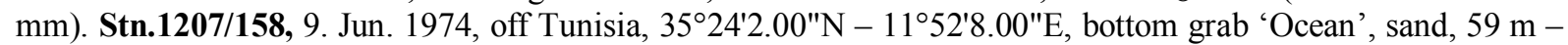
$1{ }^{\jmath}(\mathrm{CW} / \mathrm{CL} 3.2 \mathrm{~mm} / 3.1 \mathrm{~mm})$. 83th cruise: Stn. 1247, 9 Apr. 1978, off eastern Spain, 40²6'2.00"N - $1^{\circ} 9^{\prime} 2.00^{\prime \prime} \mathrm{E}$, bottom grab 'Ocean', clayish sand, $90 \mathrm{~m}-1 \delta^{\lambda}$ dam. (CW/CL $6.9 \mathrm{~mm} / 6.3 \mathrm{~mm}$ ). Stn. 1262/55, 24 Apr. 1978, off western Sicily, 37 $40^{\prime} 0.01^{\prime \prime} \mathrm{N}-12^{\circ} 3^{\prime} 0.00^{\prime \prime} \mathrm{E}$, beam trawl, rock with algae, $21 \mathrm{~m}-1$ q $(\mathrm{CW} 9.7 \mathrm{~mm} / 9.2 \mathrm{~mm})$. Stn.

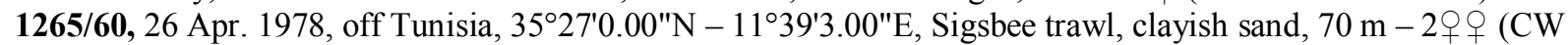
9.4, $9.9 \mathrm{~mm} / 8.0,8.8 \mathrm{~mm}$ ). Stn. 1266, 26 Apr. 1978, off Tunisia, $35^{\circ} 22^{\prime} 0.00^{\prime \prime} \mathrm{N}-35^{\circ} 22^{\prime} 0.00^{\prime \prime} \mathrm{S}$, beam trawl, sand,

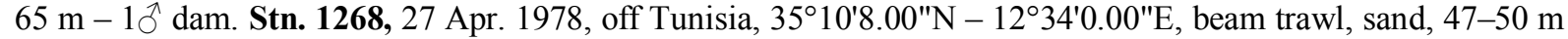

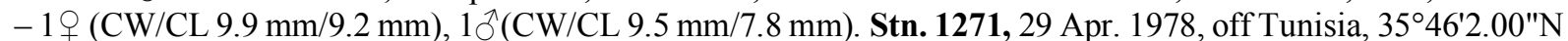
- 14 53'8.00"E, beam trawl, sand, $70 \mathrm{~m}-1$ 우 (CW/CL $7.2 \mathrm{~mm} / 6.7 \mathrm{~mm}), 10^{\lambda}$ (CW/CL $\left.9.8 \mathrm{~mm} / 8.2 \mathrm{~mm}\right) .87 \mathrm{th}$

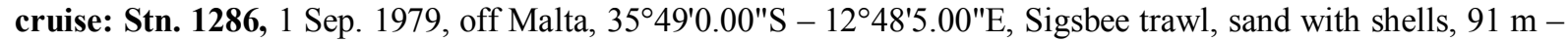
1 ㅇ (CW/CL 13.9 mm/12.2 mm). Stn. 1288, 2 Sep. 1979, off Malta, 35³8'60.00"N - 15 1'7.00"E, Sigsbee trawl, clayish sand, $97 \mathrm{~m}-1$ ( $(\mathrm{CW} / \mathrm{CL} 11.1 \mathrm{~mm} / 10.1 \mathrm{~mm})$. Stn. 1305, 14 Sep. 1979, off western Sicily, 37³1'9.00"N $-11^{\circ} 46^{\prime} 4.00^{\prime \prime E}$, beam trawl, clayish sand, $75 \mathrm{~m}-1$ 으 (CW/CL $\left.7.8 \mathrm{~mm} / 7.3 \mathrm{~mm}\right)$. Stn. 1314, $18 \mathrm{Sep}$. 1979 , off Tunisia, $35^{\circ} 31^{\prime} 4.00^{\prime \prime} \mathrm{N}-12^{\circ} 2^{\prime} 6.00^{\prime \prime} \mathrm{E}$, beam trawl, clayish sand, $76 \mathrm{~m}-1$ 우 (CW/CL $\left.8.5 \mathrm{~mm} / 8.0 \mathrm{~mm}\right)$. Stn. 1317,

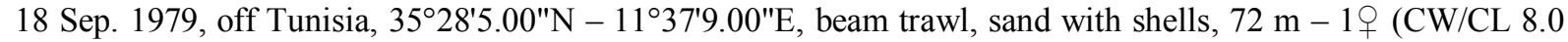
$\mathrm{mm} / 7.4 \mathrm{~mm}), 1 \mathrm{O}^{\lambda}(\mathrm{CW} / \mathrm{CL} 9.6 \mathrm{~mm} / 8.2 \mathrm{~mm})$. 89th cruise:-Stn. 1386, $1 \mathrm{Sep} .1980$, off Tunisia, 34 52'60.00"S $-12^{\circ} 45^{\prime} 5.00^{\prime \prime} \mathrm{V}$, Sigsbee trawl, sand, $110 \mathrm{~m}-1$ 우 (CW/CL $\left.10.1 \mathrm{~mm} / 9.2 \mathrm{~mm}\right), 1{ }^{\lambda}$ (CW/CL $\left.6.2 \mathrm{~mm} / 5.2 \mathrm{~mm}\right)$. Stn. 1398, 7 Sep. 1980, off western Sicily, 37² $3^{\prime} 6.00^{\prime \prime} \mathrm{N}-12^{\circ} 16^{\prime} 5.00^{\prime \prime} \mathrm{V}$, Sigsbee trawl, sand, $70 \mathrm{~m}-1$ ㅇ $(\mathrm{CW} / \mathrm{CL} 8.2$ $\mathrm{mm} / 7.3 \mathrm{~mm})$.

Remarks. There were 8 males and 12 females in the collected material. In general, all characters agree with previously published description (Froglia \& Manning 1982). Some variabilities, like the shape of the front or the anterolateral teeth, were recorded during examination of mainly small specimens. Variability of the carapace size was: $\widehat{\delta} \widehat{C W}$ CWL $3.2-$ $9.8 \mathrm{~mm} / 3.1-8.2 \mathrm{~mm}$, o $ᄋ$ CW/CL 7.2-13.9 mm/6.7-12.2 mm, with CW/CL ratio 1.03-1.195. Most important morphological characters are: (1) the front with three teeth or lobes projecting distinctly beyond the orbit line; (2) five anterolateral teeth, the 5th largest, pointed and directed mostly forward; (3) the cheliped carpus with a relatively short and obtuse internal tooth and with a distinctive tubercle on the outer surface.

Habitat. According to Froglia \& Manning (1982), the most preferred substrate is muddy sand in depths between 5-73 m. Our sample are mainly from sand, clayish sand, sand with shells, and rocks covered by algae. Depths reached to $110 \mathrm{~m}$, what distinctly overreaches the published depth range (above).

Distribution. According to Froglia \& Manning (1982), the known distribution of L. maculatus is restricted to the Mediterranean. It has been reported from the coast of Spain and from the Adriatic and Tyrrhenian Sea to the coast of Israel (Holthuis \& Gotlieb 1958; Zariquiey Álvarez 1968; Froglia \& Manning 1982). Despite its areal probably covers the whole Mediterranean, the mentioned records are only from northern regions. Fourteen specimens examined in this study are from the region near Tunisia and off eastern Malta, from where L. maculatus was not reported before. 
Liocarcinus navigator (Herbst, 1794) Figs 4 A-C, 9

Portunus arcuatus. Palmer, 1927: 884-885, fig. 4.

Macropipus arcuatus. Zariquiey Álvarez, 1968: 369 figs. 116 d-h, 120 a, 122 c, 123 a; Christiansen, 1969: 57, fig. 21 ; map 15.

Liocarcinus navigator. $\mathrm{Ng}$ et al., 2008: 149.

Polybius arcuatus. Udekem d'Acoz, 1999: 222.

Material examined. R/V ,Akademik A. Kovalevskii“, 89thcruise: Stn. 1390, 2 Sep. 1980, off Tunisia, $35^{\circ} 18^{\prime} 3.00^{\prime \prime} \mathrm{N}-12^{\circ} 4^{\prime} 4.00^{\prime \prime E}$, Sigsbee trawl, sand, $55 \mathrm{~m}-1{ }^{\top}$ (CW/CL $\left.6.9 \mathrm{~mm} / 5.9 \mathrm{~mm}\right)$.

Remarks. A single small specimen examined agrees well with previous description (Palmer 1927; Christiansen 1969). The most important characters are: (1) front entire; (2) very small 4 th anterolateral tooth; (3) smooth outer surface of the cheliped carpus. Only the CW/CL ratio 1.16 is lower in the present specimen in relation to published range, 1.25-1.33 (Palmer 1927; Christiansen 1969), which evidently is consequence of a very small size of the specimen. The species reaches about $30 \mathrm{~mm}$ in CW in mature specimens (Christiansen, 1969).

Habitat. Liocarcinus navigator has previously been reported from sandy, gravel or rocky bottoms, and from the depths to $108 \mathrm{~m}$, but mostly of about $50 \mathrm{~m}$ (Zariquiey Álvarez 1968; Manning \& Holthuis 1981; Udekem d'Acoz 1999; Ateş 2006). The present sample was collected from sandy bottom in depth $55 \mathrm{~m}$.

Distribution. This species is spread in the Eastern Atlantic, from Mauretania to Norway, and it is also common in the Mediterranean and Black Seas (Zariqueiey Álvarez 1968; Christiansen 1969). The present specimen was collected off the coast of Tunisia, from where L. navigator already was previously reported (Christiansen 1969; Holthuis 1987).

\section{Liocarcinus vernalis (Pennant, 1816) Figs 5 A-C, 9}

Portunus barbatus. Palmer, 1927: 900.

Macropipus vernalis. Zariquiey Álvarez, 1968: 377-379, figs. 119 c, 121 c, 123 f, 124 f.

Liocarcinus vernalis. Udekem d'Acoz \& Rappé, 1991: 95-99, figs. 2, 5, 8, 11.

Polybius (Polybius) vernalis. Udekem d'Acoz, 1999: 222.

Material examined. R/V ,Akademik A. Kovalevskii ${ }^{6,}$, 89th cruise: Stn. 1390, 20 Sep. 1980, the Alboran Sea, $35^{\circ} 49^{\prime} 0.00^{\prime \prime} \mathrm{N}-3^{\circ} 16^{\prime} 0.00^{\prime \prime} \mathrm{W}$, bottom grab 'Ocean', rough sand, $130 \mathrm{~m}-1$ q juv. (CW/CL $6.1 \mathrm{~mm} / 5.0 \mathrm{~mm}$ ).

Remarks. Only single specimen was examined, with the CW/CL ratio of the carapace 1.22. Most characters more or less correspond with a previous description provided by Zariquiey Álvarez (1968). Together with that, some minor differences, caused mainly by a small size of the specimen available were found. Among the most important morphological characters of $L$. vernalis are: (1) front with three teeth, the median tooth lower than the lateral ones; (2) the carapace relatively smooth, with a fine granulation; (3) the cheliped carpus with well depeloped posteroexternal angle and a low tubercle on the outer surface.

Habitat. Liocarcinus vernalis is characterized as shallow-water species mostly inhabiting depths of about $10 \mathrm{~m}$, and with its maximum depth range $100 \mathrm{~m}$. (Zariquiey Álvarez 1968; Udekem d'Acoz \& Rappé 1991; Udekem d'Acoz 1999). Our specimen was caught in the depth of $130 \mathrm{~m}$, which overreaches the known depth range. Preferred substrate is mainly sand (Udekem d'Acoz \& Rappé 1991), like in our case.

Distribution. Areal of this species covers the Eastern Atlantic from the Cape Blanc to the southern end of the North Sea, and the whole Mediterranean; it also was reported from the Black Sea (Monod 1956; Holthuis \& Gottlieb 1958; Zariquiey Álvarez 1968; Pipitone \& Arcuelo 2003). Our sample is from the Alboran Sea, from where the species was previously reported by Holthuis (1987). 
A

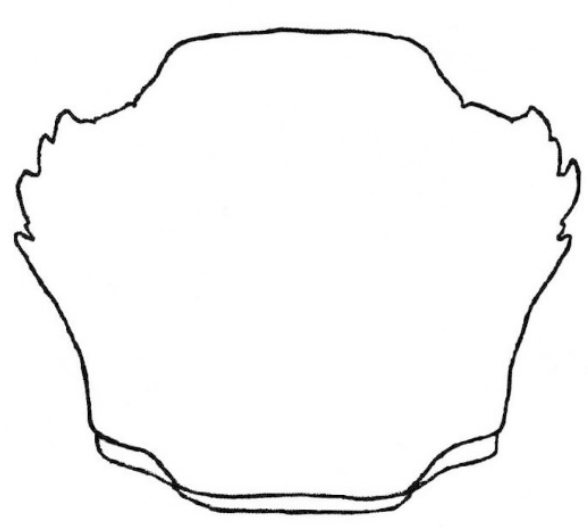

\section{$5 \mathrm{~mm}$}

B

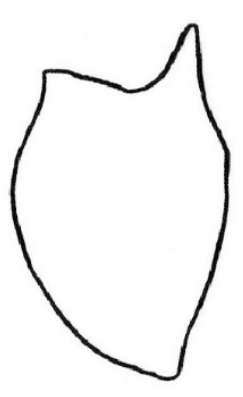

C

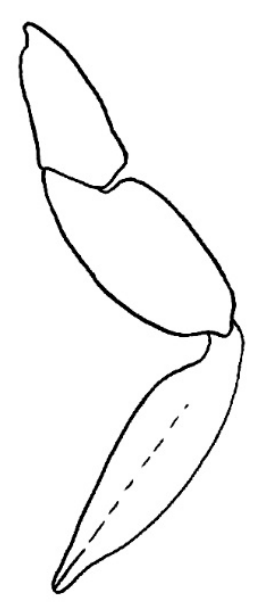

$1 \mathrm{~mm}$

Fig 4: Liocarcinus navigator (Herbst, 1794). A, carapace; B, carpus of left cheliped; C, fifth ambulatory leg.

A

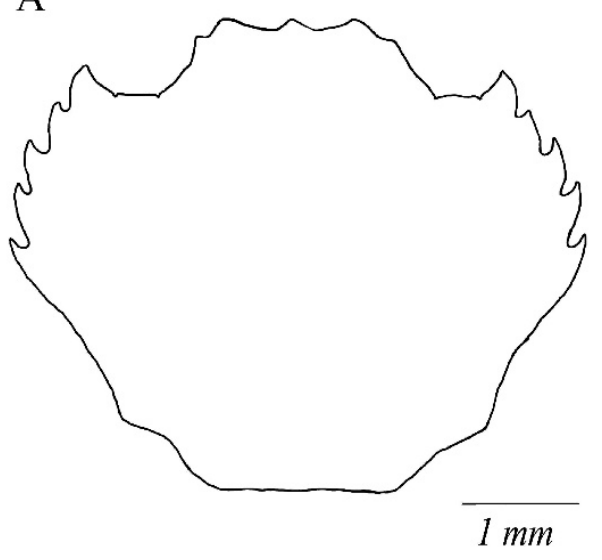

B

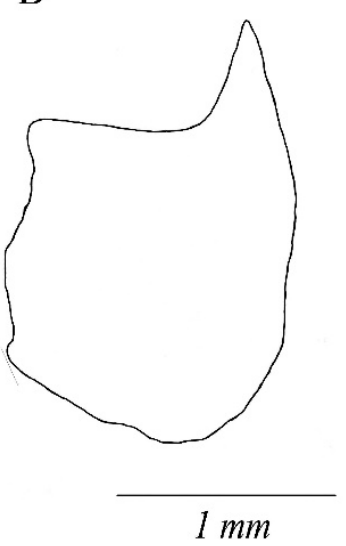

C

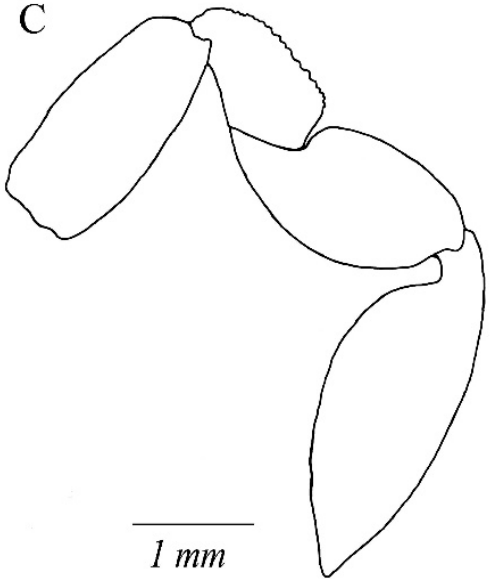

Fig 5: Liocarcinus vernalis (Pennant, 1816). A, carapace; B, carpus of left cheliped; C, fifth ambulatory leg.

A

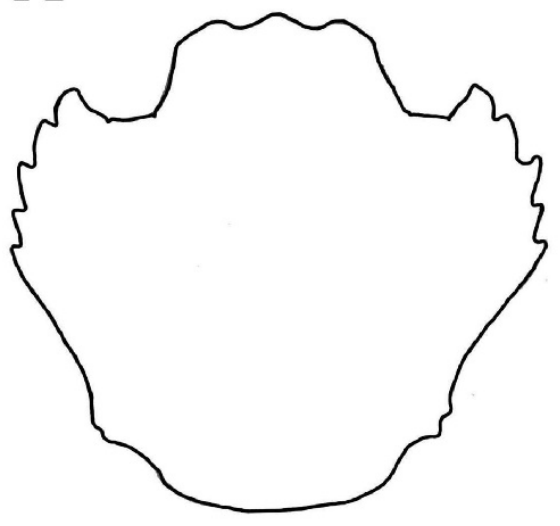

$5 \mathrm{~mm}$
B

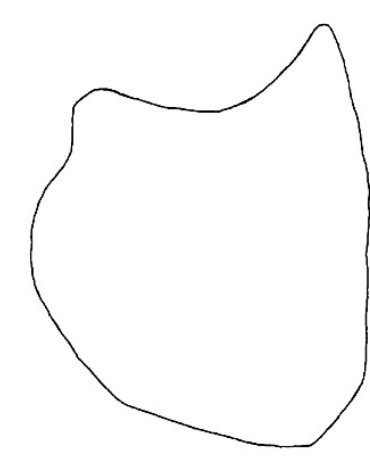

$1 \mathrm{~mm}$
C

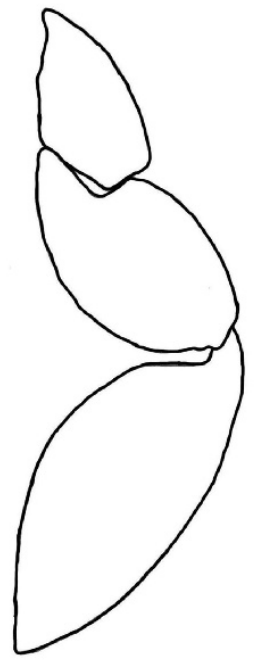

$1 \mathrm{~mm}$

Fig 6: Liocarcinus zariquieyi, Gordon, 1968. A, carapace; B, carpus of left cheliped; C, fifth ambulatory leg. 


\section{Liocarcinus zariquieyi Gordon, 1968 Figs 6 A-C, 9}

Macropipus zariquieyi. Zariquiey Álvarez, 1968: 374, figs. 120 b, 127 c.

Polybius zariquieyi. Udekem d'Acoz, 1999: 224.

Material examined. R/V ,Akademik A. Kovalevskii“, 83th cruise: Stn. 1262/55, 24 Apr. 1978, off western

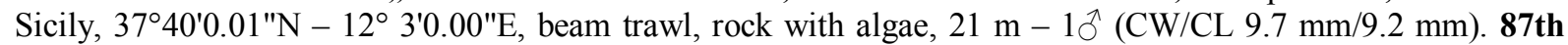

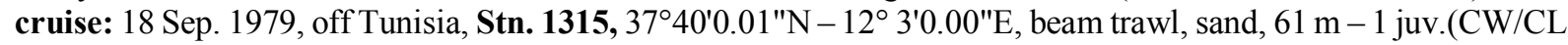
$6.1 \mathrm{~mm} / 5.5 \mathrm{~mm})$. 89th cruise: Stn. 1390, 2 Sep. 1980, off Tunisia, 35¹8'3.00"N - 12 4'4.00"E, Sigsbee trawl, sand, $55 \mathrm{~m}-1$ ( $(\mathrm{CW} / \mathrm{CL} 9.3 \mathrm{~mm} / 8.4 \mathrm{~mm})$.

Remarks. Three specimen of this species have been examined: 1 male, 1 female and 1 juvenile $(\mathrm{CW} / \mathrm{CL} 6.1-9.7 \mathrm{~mm} / 5.5-9.2 \mathrm{~mm}$ ), with the carapace $\mathrm{CW} / \mathrm{CL}$ ratio $1.06-1.11$. External morphology of the specimens examined correspond with previously published data (Zariquiey Álvarez 1968; Froglia \& Manning 1982; Garcia Raso \& Manjón-Cabeza 1996). The most important characters are: (1) front with three lobes or blunt teeth; (2) 4th anterolateral tooth greater then 5th tooth; (3) the cheliped carpus with a relatively short and blunt anterointernal tooth and with a smooth outer surface.

Habitat. According to Froglia \& Manning (1982), L. zariquieyi prefers sandy and gravel substrates in depths between 10-60 m. Regarding the collection data from our material, one specimen was caught on a rock covered by algae. Another of the present specimens was collected from the depth of 61 meters, which slightly overreaches the mentioned depth range.

Distribution. Liocarcinus zariquieyi is known from the Eastern Atlantic, from the Canary Islands to the British Islands, and from the Mediterranean (Froglia \& Manning 1982). It was reported from the Tyrrhenian and Adriatic Sea, Sardinia and Western Sicily waters (Froglia \& Manning 1982; Pipitone \& Arcuelo 2003). There are also some reports from eastern coast of Spain (Zariquiey Álvarez 1968). Our material contains three specimens. A single one was caught off western Sicily, and two ones between Tunisia and Lampedusa Island. The latter is a new locality for this species.

\section{Genus Macropipus Prestandrea, 1833}

\section{Macropipus tuberculatus (Roux, 1830) Figs 7 A-C, 9}

Portunus tuberculatus. Palmer, 1927: 894-896, fig 9; Bouvier, 1940: 241, fig. 156, pl. IX, fig 7; Monod, 1956: 180-183, figs. 207-209.

Macropipus tuberculatus. Zariquiey Álvarez, 1968: 374, figs. 119 f, 122 g, 123 c, 124 d; Christiansen, 1969: 6667, fig. 26; map 20.

Polybius (Macropipus) tuberculatus. Udekem d'Acoz, 1999: 219.

Material examined. R/V ,Akademik A. Kovalevskii“", 74th cruise: Stn. 1182/129, 1 Jun. 1974, off eastern Spain, $40^{\circ} 17^{\prime} 8.00 " \mathrm{~N}-0^{\circ} 47^{\prime} 8.00 " \mathrm{E}$, bottom grab 'Ocean', fine sand, $77 \mathrm{~m}-10^{\lambda}(\mathrm{CW} / \mathrm{CL} 25.7 \mathrm{~mm} / 17.5 \mathrm{~mm})$. Stn. 1191/128, 2 Jun. 1974, off eastern Spain, 39 $9^{\circ} 58^{\prime} 0.00^{\prime \prime} \mathrm{N}-0^{\circ} 58^{\prime} 2.00^{\prime \prime} \mathrm{E}$, bottom grab 'Ocean', sand, $125 \mathrm{~m}, 1$ juv. (CW/CL $9.1 \mathrm{~mm} / 7.0 \mathrm{~mm}$ ). Stn. 1192/129, 2 Jun. 1974, off eastern Spain, 40 $3^{\prime} 60.00^{\prime \prime} \mathrm{N}-0^{\circ} 56^{\prime} 1.00^{\prime \prime} \mathrm{E}$, bottom grab 'Ocean', sand with broken shells, $105 \mathrm{~m}, 2 \AA \widehat{\partial}$ (CW/CL 14.3, $20.8 \mathrm{~mm} / 9.7,13.3 \mathrm{~mm}$, resp.). 83th cruise: Stn. 1246, 9 Apr. 1978, off eastern Spain, $40^{\circ} 14^{\prime} 05.00 " \mathrm{~N}-1^{\circ} 09^{\prime} 02.00^{\prime \prime} \mathrm{E}$, Sigsbee trawl, sand with clay and shells, $110 \mathrm{~m}-1$ juv. (CW/CL $4.5 \mathrm{~mm} / 4.1 \mathrm{~mm}$ ).

Remarks. Five specimens were examined: 3 males, 1 female and 2 juvenile (CW/CL 4.5 - 25.7 $\mathrm{mm} / 4.1-17.5 \mathrm{~mm}$ ), with their carapace $\mathrm{CW} / \mathrm{CL}$ ratio $1.1-1.56$. All main characters of adults clearly agree with published data (Palmer 1927; Zariquiey Álvarez 1968; Christiansen 1969). However, juveniles might morphologically differ. There were noticeable differences in CW/CL ratio, the cheliped carpus shape, and the 5th pair of pereiopodes dactylus shape (figs. 8 a-f). Typical morphological characters for M. tuberculatus are: (1) the front with three distinct sharp teeth, with the median tooth more prominent than lateral ones; (2) a distinctive granulation over the whole carapace, and distinctive elevated carapacial regions; (3) 5th anterolateral tooth of the carapace greater than the others; (4) the cheliped carpus with a very long and sharp inner 
A

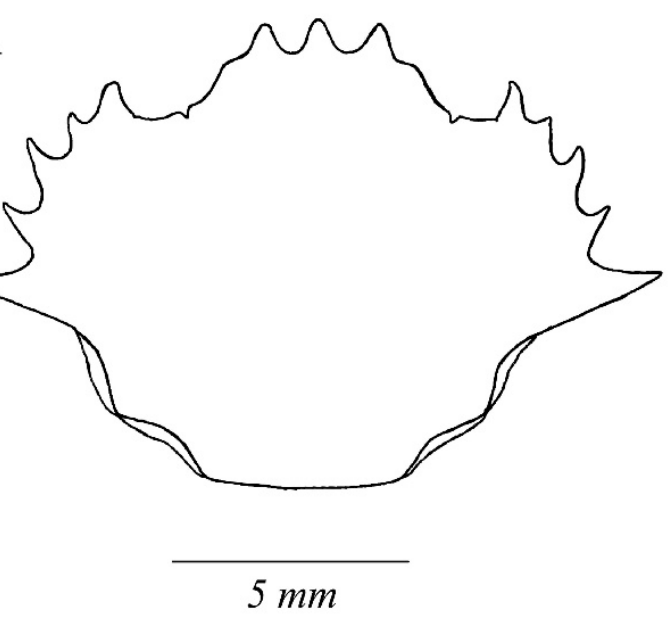

D

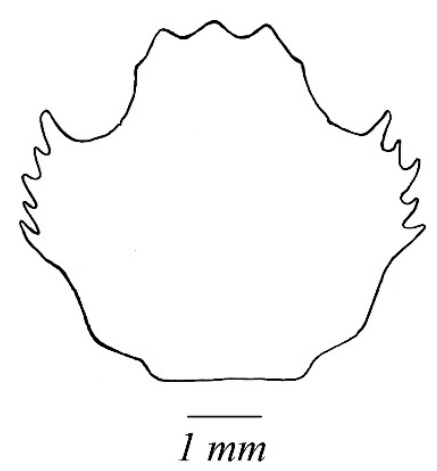

B

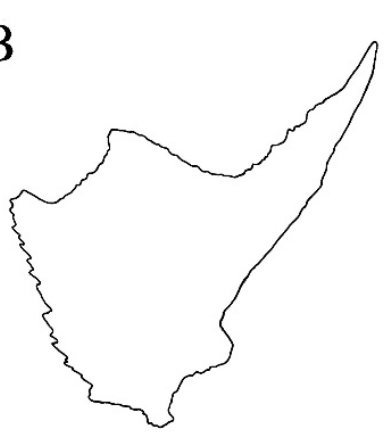

C

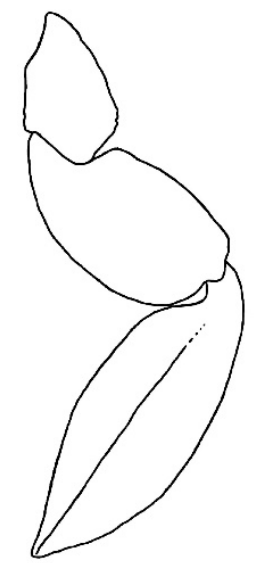

$\overline{1 \mathrm{~mm}}$

E

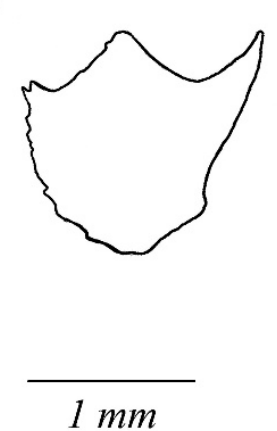

F

$\overline{1 \mathrm{~mm}}$

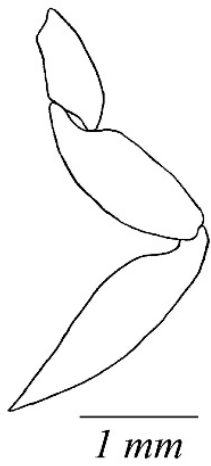

Fig 7: Macropipus tuberculatus (Roux, 1830), mature (A-C); juvenile (D-F); A, D, carapace ; B, E, carpus of left cheliped ; C, F, fifth ambulatory leg
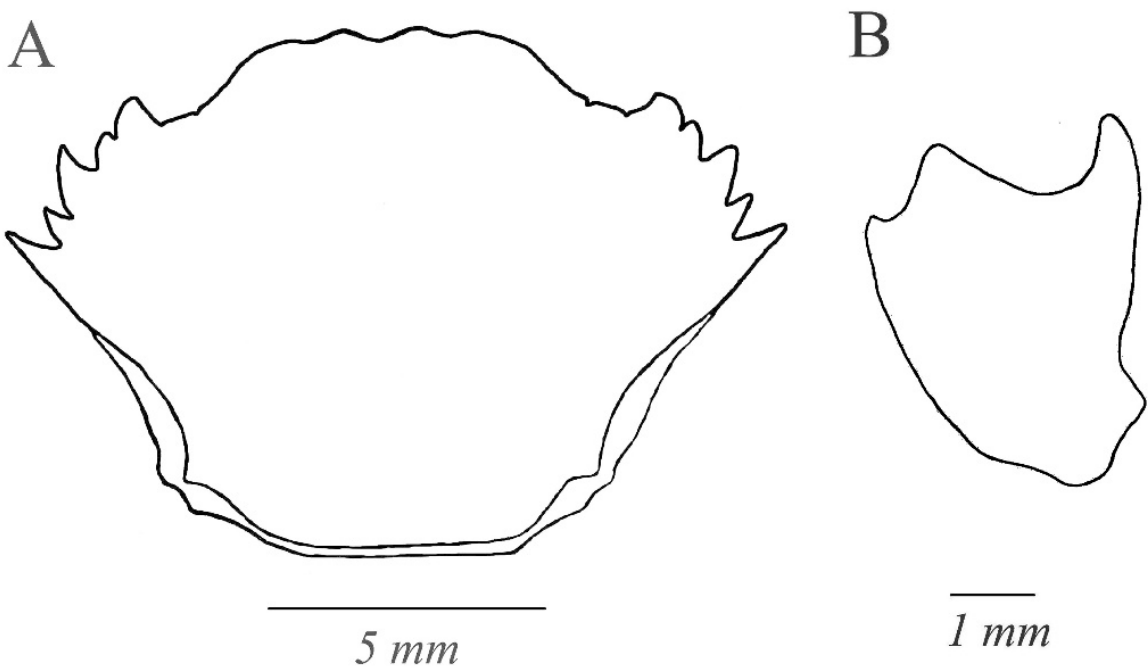

C

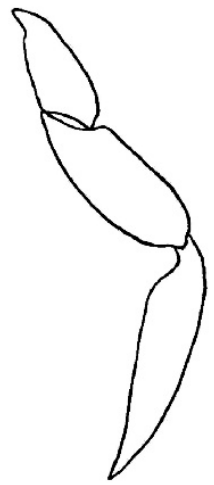

$\overline{1 \mathrm{~mm}}$

$1 \overline{\mathrm{mm}}$

Fig 8: Bathynectes longipes (Risso, 1816). A, carapace; B, carpus of left cheliped; C, fifth ambulatory leg. 
tooth and a strong tubercle on the outer surface; (5) the 5th leg dactylus broadly lanceolate and with a clearly visible median rib.

Habitat. Preferred substrates are sand and clay, and depths reaching to $748 \mathrm{~m}$ (Zariquiey Álvarez 1968; Christiansen 1969; Udekem d'Acoz 1999). Our specimens were collected from sandy and muddy bottom in depths between 77 and $125 \mathrm{~m}$.

Distribution. Macropipus tuberculatus was reported from the Eastern Atlantic (from Norway to Azores and Senegal) and the Mediterranean (Monod 1956; Christiansen 1969; Udekem d'Acoz 1999). All the present material is completely from the eastern Spanish waters from where M. tuberculatus already was previously reported (Zariquiey Álvarez 1968; Christiansen 1969; Holthuis 1987).

\section{Genus Bathynectes Stimpson, 1861}

\section{Bathynectes longipes (Risso, 1816) Figs 8 A-C, 9}

Bathynectes longipes. Bouvier, 1940: 246, fig. 158, pl. 9, fig 12; Zariquiey Álvarez, 1968: 382, figs. 14 e, 122 a, 125 b, c, 126 b, 127 e, f.; Udekem d'Acoz, 1999: 217-218.

Material examined. R/V ,Akademik A. Kovalevskii“, 90th cruise: Stn. 1382/4, 17 Aug. 1980, off northern Crete, approx. $35^{\circ} 22^{\prime} \mathrm{N}-25^{\circ} 22^{\prime} \mathrm{E}$, Sigsbee trawl, clayish sand, $94 \mathrm{~m}-2$ ( $(\mathrm{CW} / \mathrm{CL} 16.3,21.7 \mathrm{~mm} / 11.6,15.1 \mathrm{~mm}$, resp.).

Remarks. There were two females in the present material (CW/CL $16.3 \mathrm{~mm} / 11.6 \mathrm{~mm}, 21.7$ $\mathrm{mm} / 15.1 \mathrm{~mm}), \mathrm{CW} / \mathrm{CL}$ ratio in between $1.40,1.43$. All main morphological characters agree well with a previous description by Bouvier (1940). For this species is typical: (1) a broad front with four low lobes; (2) five anterolateral teeth, with 3rd and 5th teeth greater than the remaining ones; (3) a distinct transverse ridge on the carapace; (4) a strong tubercle on the outer surface of the cheliped carpus; (5) very long and slender walking legs; (6) the 5th leg with a slender, lanceolate, dactylus.

Habitat. According to Udekem d'Acoz (1999), B. longipes prefers substrates like sand, gravel and clay in depths to $226 \mathrm{~m}$. Samples of our material were collected from sand with clay, in a depth of $94 \mathrm{~m}$.

Distribution. In the Eastern Atlantic, B. longipes was reported from the coast of Portugal (Zariquiey Álvarez 1968) to the coast of the Great Britain (Bouvier 1940). The species is common in the Mediterranean Sea, from the cost of Spain to the Marmara Sea (Manning \& Holthuis 1981). The present record from the northern Crete corresponds well with previously published distributional data (Udekem d'Acoz 1999).

\section{Discussion}

In the Mediterranean Sea, the family Portunidae is represented, together with several representatives of alien species from the genera Charybdis De Haan, 1833, Carupa Dana, 1851, Callinectes Stimpson, 1860, and Thalamita Latreille, 1829 (Zenetos et al. 2005), by species of the following native genera: Carcinus Leach, 1814, Necora Holthuis, 1987, Polybius Leach,1820, Xaiva MacLeay, 1838, Portunus Weber, 1795, Portumnus Leach, 1814, Bathynectes, Macropipus, and Liocarcinus (Zariquiey Álvarez 1968; Manning \& Holthuis 1981). In the present material, 64 specimens from eight species of the portunid crabs were identified as belonging to the Mediterranean native genera Liocarcinus, Macropipus and Bathynectes. These species were collected from 35 stations (i.e., $28 \%$ from the total number of. 125 stations) sampled. The low number of the frequency of occurrence of the portunids among the samples is evidently due to deeper waters, while most of portunid species prefer shallow water habitats (Zariquiey Álvarez 1968; Manning \& Holthuis 1981; Froglia \& Manning 
1982), excluding, e.g., L. depurator, M. tuberculatus and B. longipes which generally inhabit deeper waters (Ateş 1999; Udekem d'Acoz 1999).

In a total, the genus Bathynectes includes five species, and the genus Macropipus four species (Ng et al. 2008). These genera were represented each by one species in the present material, B. longipes and $M$. tuberculatus. The present distributional as well as bathymetric data fallen well within known ranges of these species (Udekem d'Acoz 1999).

The most speciose genus of the Mediterranean portunid crabs is Liocarcinus. According to $\mathrm{Ng}$ et al. (2008), the genus Liocarcinus includes 12 species distributed predominantly in the Eastern Atlantic (Zariquiey Álvarez 1968; Manning \& Holthuis 1981; Holthuis 1987), excluding L. corrugatus occurring also in the Indo-West Pacific Area eastwards to Australia (Stephenson 1972). The present material contains six species of the genus: L. corrugatus, $L$. depurator, L. maculatus, L. navigator, L. vernalis and L. zariquieyi. The most dominant species in the examined material were: L. maculatus (19 spms), L. depurator (17 spms), and $L$. corrugatus (16 spms). Other three species were represented only by a single specimen ( $L$. vernalis, L. navigator), or three specimens (L. zariquieyi).

Liocarcinus maculatus and L. zariquieyi were collected in the Mediterranean central basin, where these species were not reported before. These species were collected between coasts of Tunisia and Lampedusa Island, and also off eastern Malta (only L. maculatus).

The bathymetric data obtained from the present portunid species correspond well with published reports, with some exceptions. Liocarcinus maculatus was collected from depths down to $110 \mathrm{~m}$, while the known reports provide the bathymetric range for the species between, 5 and $73 \mathrm{~m}$ (Froglia \& Manning 1982). A single collected specimen of $L$. vernalis was caught in the depth of $130 \mathrm{~m}$. This species is known as inhabiting shallow waters, exceptionally down to 100 m (Udekem d'Acoz \& Rappé 1991).

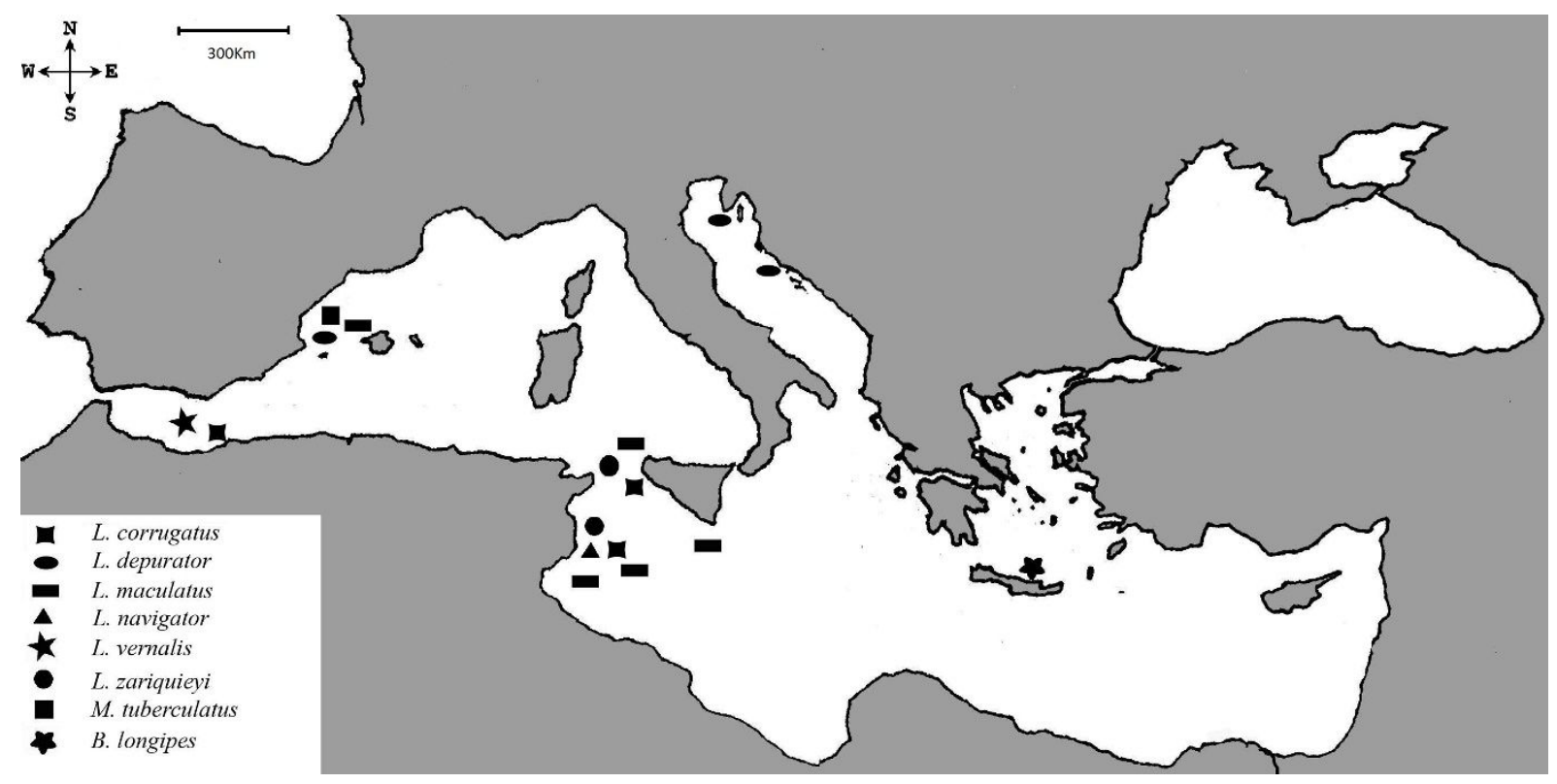

Fig 9: Present localities of the portunid crabs in the Mediterranean Sea.

Acknowledgements: The authors are indebted to Institute of Biology of the Southern Seas, National Ukrainian Academy of Science, Sevastopolfor providing material collected by previous Soviet expeditions for our study, and to Dr. N.A. Zarenkov (retired, Lomonosov Moscow State University) for pointing out the senior author, many years ago, to that interesting Mediterranean material. This work was supported by the project 'Institute of Environmental Technologies', Ostrava (CZ.1.05/2.1.00/03.0100 and ED2.1.00/03.0100), funded jointly by the EU Operational Program 'Research and Development for Innovations'. The study was also partially facilitated by supports from the Czech National Committee for cooperation with IOC UNESCO, and by the Student Grant Competition, Faculty of Sciences, University of Ostrava (sgs05/PřF/2012). 


\section{References}

Abelló P. (1989): Feeding habits of Macropipus tuberculatus (Brachyura, Portunidae) off the Catalan coast (NW Mediterranean). - Misc. Zool. 13: 45-50.

Ateş, A.S. (1999): Liocarcinus depurator (Linnaeus, 1758) and Brachynotus sexdentatus (Risso, 1827) (Decapoda, Brachyura): two new records for the Turkish Black Sea fauna. - Turkish Journal of Zoology 23: 115-118.

Ateş A.S., Katağan T. \& Kocataş A. (2006): Bathymetric distribution of decapod crustaceans on the continental shelf along the Aegean coasts of Turkey. - Crustaceana 79 (2): 129-141.

Bouvier E.-L. (1940): Décapodes marcheurs. - Faune de France 37: 1-404.

Christiansen M.E. (1969): Decapoda Brachyura. - Marine Invertebrates of Scandinavia 2: 1-141.

De Grave S., Pentcheff N.D., Ahyong S.T., Chan T.-Y., Crandall K.A., Dworschak P.C., Felder D.L., Feldmann R.M., Fransen C.H.J.M., Goulding L.Y.D., Lemaitre R., Low M.E.Y., Martin J.W., Ng P.K.L., Schweitzer C.E., Tan S.H., Tshudy D. \& Wetzer R. (2009): A classification of living and fossil genera of decapod crustaceans. - The Raffles Bulletin of Zoology, Suppl. 21: 1-109.

Froglia C. \& Manning R.B. (1982): Notes on Liocarcinus pusillus (Leach) and related species. - Quaderni del Laboratorio di Tecnologia della Pesca 3(2-5): 257-266.

García Raso J.E. \& Manjón-Cabeza M.E. (1996): New record of Liocarcinus mcleayi (Barnard, 1947), new combination (Decapoda, Brachyura, Portunidae) from south Europe. - Crustaceana 69 (1): 84-93.

Holthuis L.B. \& Gottlieb E. (1958): An annotated list of the decapod Crustacea of the Mediterranean coast of Israel, with an appendix listing the Decapoda of the eastern Mediterranean. - Bulletin of the Research Council of Israel Section B: Zoology 7B(1-2): 1-126.

Holthuis L.B. (1987): Vrais crabes. Pp. 322-367. In: W. Fischer, M.-L. Bauch ot \& M. Schneider (Ed.): Fiches FAO d'identification des espèces pour les besoins de la pêche. (Révision 1). Méditerranée et mer Noire. Zone de pêche 37 . Volume I. Végétaux et Invertébrés. FAO, Rome.

Manning R.B. \& Holthuis L.B. (1981): West African brachyuran crabs (Crustacea: Decapoda). - Smithsonian Contributions to Zoology 306: 1-379.

Mon od T. (1956): Hippidea et Brachyura ouest-africains. - Mémoires de l'Institut Français d'Afrique Noire 45 : $1-674$.

Ng P.K.L., Guin ot D. \& Davie P.J.F. (2008): Systema Brachyurorum: Part I. An annotated checklist of extant brachyuran crabs of the world. - The Raffles Bulletin of Zoology, Supplement n.17: 1-286.

Palmer R. (1927): A revision of the genus "Portunus" (A. Milne Edwards, Bell, etc.). - Journal of the Marine Biological Association of the United Kingdom 14(4): 877-908.

Pipitone C. \& Arcuelo M. (2003): The marine Crustacea Decapoda of Sicily (central Mediterranean Sea): a checklist with remarks on their distribution. - Italian Journal of Zoology 70: 69-78.

Stephenson W. (1972): Portunid crabs from the Indo-West-Pacific and Western America in the Zoological Museum, Copenhagen (Decapoda, Brachyura, Portunidae). - Steenstrupia 2(9): 127-156.

Števcic Z. (1969): Lista desetonožnih rakova Jadrana. - Biološki Vestnik, Ljubljana 17: 125-134.

Streftaris N., Zenetos A. \& Papathanassiou E. (2005): Globalisation in marine ecosystems: the story of non-indigenous marine species across European seas. - Oceanography and Marine Biology: An Annual Review 43: 419-453.

Udekemd'Acoz C.d' (1999): Inventaire et distribution des crustacés décapodes de l'Atlantique nord-oriental, de la Méditerranée et des eaux continentals adjacentes au nord de $25^{\circ} \mathrm{N}$. - Patrimonies Naturels (M.N.H.N. /S.P.N.) 40: 1-383.

Udekemd'Acoz C.d' \& Rappé G. (1991): Présence et abondance de Liocarcinus vernalis (Risso, 1816) dans la baie sud de la Mer du Nord (Decapoda, Brachyura, Portunidae). - Crustaceana 61 (1): 95-99.

Zariquiey Álvarez R. (1968): Crustáceos Decápodos Ibéricos. - Investigación Pesquera 32: 1-510.

Zenetos A., Çinar M.E., Pancucci-Papadopoulou A.M., Hamerlin J.G., Furnari G., Andaloro F., Bellou N. Streftaris N. \& Zibrowius H. (2005): Annotated list of marine alien species in the Mediterranean with records of the worst invasive species. - Mediterranean Marine Science 6/2: 63-118.

Authors' addresses: Milan Koch \& Zdeněk Ďuriš, University of Ostrava, Faculty of Science, Department of Biology and Ecology, Chittussiho 10, 71000 Ostrava, Czech Republic

E-mail: milan.foxus@seznam.cz 